"Interaction effect between product and process innovation: the case of Tunisian banks"

$\begin{array}{ll} & \text { Mabrouk Abir } \\ \text { AUTHORS } & \text { Dhouibi Raoudha } \\ & \text { Rouetbi Emna }\end{array}$

Rouetbi Emna

ARTICLE INFO

Mabrouk Abir, Dhouibi Raoudha and Rouetbi Emna (2016). Interaction effect

between product and process innovation: the case of Tunisian banks. Banks and Bank Systems, 11(1), 60-70. doi:10.21511/bbs.11(1).2016.07

DOI

http://dx.doi.org/10.21511/bbs.11(1).2016.07

RELEASED ON

Monday, 25 April 2016

JOURNAL

"Banks and Bank Systems"

FOUNDER

LLC "Consulting Publishing Company "Business Perspectives"

NUMBER OF REFERENCES

0

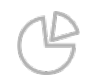

NUMBER OF FIGURES

0

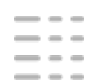

NUMBER OF TABLES

0

(C) The author(s) 2021. This publication is an open access article. 
Mabrouk Abir (Africa), Dhouibi Raoudha (Africa), Rouetbi Emna (Africa)

\title{
Interaction effect between product and process innovation: the case of Tunisian banks
}

\begin{abstract}
The authors examine the impact of the relationship between two types of financial innovation and bank performance. The research attempts to test hypotheses that are not yet validated by previous studies focusing on the financial services industry, thus, giving the study an exploratory look. The authors try, specifically, to determine the interaction effect of both types of financial innovation on bank performance and, then, try to enrich innovation theory with new hypotheses on product and process innovation. The results show that Tunisian banks have begun, probably, to see the importance or the need for the simultaneous adoption of two types of financial innovation since 1995 to improve their poor performance. The authors also find that the interaction effect of product and process innovation reduces profitability. However, efficiency is achieved in terms of market share and value. The authors conclude that financial innovation is a value creation instrument for Tunisian banks.
\end{abstract}

Keywords: financial innovation, product innovation, process innovation, performance, efficiency, banks. JEL Classification: C33, C36, G21, G28, O31, O33.

\section{Introduction}

In general, innovation is one of the most raised issues in social sciences. Indeed, in an environment with high turbulence, a successful innovation may equip a company with a competitive advantage and, thus, a superior performance. Interest in financial innovation has become increasingly important with the recent development in the banking business, where it became essential that banking institutions should try to increase their arsenal of innovation. This can only be achieved through constantly innovating products and processes (Porter, 2004), despite the fact that financial innovation is often accused during international crises (Betz, 2016) ${ }^{1}$.

This study focuses on the dynamics of financial innovation and its implication on the efficiency of Tunisian banks. Indeed, after the 2011 revolution and the political instability that followed, the Tunisian economy has experienced unprecedented difficulties in 2011, a situation that had a negative impact on the financial strength of the Tunisian banking system.

Specifically, our interest focuses on determining the real impact of financial innovation on Tunisian banks' performance, given their environmental and organizational characteristics. To this end, we examine, on the one hand, the individual impact of each type of innovation and, on the other hand, the impact of the interactive relationship between the two types of financial innovation and banking performance.

(C) Mabrouk Abir, Dhouibi Raoudha, Rouetbi Emna, 2016.

Mabrouk Abir, Assistant Professor of Finance, Higher Institute of Commerce and Accountancy-Bizerte, Africa.

Dhouibi Raoudha, Assistant Professor of Finance, Faculty of Law, Economics and Management of Jendouba, Africa.

Rouetbi Emna, Assistant Professor of Finance, Higher Institute of Finance and Taxation-Sousse, Africa.

${ }^{1}$ It proposes the use of ICT technologies in international banking, increased frequency and intensity of the international financial crises. At the end of the twentieth century, we began to witness, globally, very destabilizing capital flows, especially during the 1997 Asian financial crisis, the 2007 Global financial crisis and the 2010 Euro crisis.
Indeed, it is admitted in the literature that innovation of products and processes mutually interact leading to a greater banking efficiency. In this study, our main objective, therefore, is to provide a better understanding of the relationship between financial innovation and banking performance.

To validate the impact of the interactive relationship between the two types of financial innovation on banking performance, we will test hypotheses that are not yet validated by previous studies examining financial services, thus, giving this study an exploratory outlook. Ultimately, our contribution pertains to enriching innovation theory with a new look into financial innovation of products and processes.

\section{The previous literature}

1.1. Typology of financial innovation. As accepted by most researchers, there are two main categories of financial innovation, namely, innovation of products and innovation of processes (Dan Awrey, 2013).

- Product innovation refers to an extension of the range of financial assets or services offered by financial institutions. It can be either at the margin, as part of a strategy of differentiation, or a breach with existing products.

- Process innovation refers to introducing new technologies related to the process of production or distribution. This is, basically, the introduction of IT and telematics in the management of payment systems.

Batiz-Lazo and Wood (2002) stipulate that product innovation focuses on the market and is, primarily, customer-driven, otherwise, introduced to meet external needs of a user or a market. However, process innovation has an internal focus, seeking 
to develop new skills and competencies and is, mainly, efficiency-driven.

Likewise, Batiz-Lazo and Woldesenbent (2006) suggest that a distinction between product and process innovation is important, insofar, as the adoption of each type needs different organizational skills. Indeed, first, product innovation needs banks to focus on customer needs, and to change behavior, and to create new ways to access banking markets. Moreover, process innovation needs banks to implement the New Technologies of Information and Communication to improve efficiency in marketing the product and ensuring a better service quality (Damanpour and Gopalakrishnan, 2001).

1.2. Synchronizing the adoption of product and process innovations. There is a wide agreement that product and process innovations affect each other and they need to be adopted together. Walker (2004) suggests that, on the one hand, one leads the other and, therefore, may be adopted in succession and, on the other hand, they complement each other and may be adopted simultaneously. The author added that organizations adopting both product and process innovation are most likely to achieve high levels of performance. In this context, Damanpour et al. (1989), studying the relationship between product and process innovation over time and their impact on firm performance, found that both types of innovation interact with each other to positively affect firm performance that changes over time depending on the dominant type of innovation (product or process). Ettlie (1995) found that developing activities, including product and process innovation, have a positive impact on firm performance. Thus, both types of innovation are necessary to maintain or improve performance.

The results of Damanpour and Gopalakrishnan (2001) confirm the need to synchronize the adoption of product and process innovation and their positive effect on banking efficiency, suggesting that to improve bank performance, introducing new products needs simultaneous introduction new processes. Buzzachi et al. (1995) also argue that introduction of new products needs the simultaneous introduction of new processes, particularly in the service industries.

1.3. Reciprocal causality between financial innovation and banking performance. By studying the impact of Internet banking on the performance of US community banks, De Young et al. (2007) raise the issue that adoption of Internet is not completely exogenous to all indicators of banking performance. The authors attempted to solve this endogeneity problem by making use of instrumental variables. An example of this is the existing two-way causality between profitability and financial innovation. Increase in $\operatorname{cost}^{2}$

\footnotetext{
${ }^{2}$ Mainly because of the expenses related to process innovation.
}

does not necessarily generate low profits because innovative banks make more revenue from noninterest income, which allows them to cover additional expenditure through the received commissions (De Young et al., 2007; Sullivan, 2000). Thus, on the one hand, financial innovation can improve bank profitability (Roberts and Amit, 2003). In turn, it allows banks to provide the funds necessary for the adoption of financial innovation ${ }^{3}$ and, thus, maintain their competitive positions (Furst et al., 2002). Moreover, De Young et al. (2007) found that banks with higher noninterest expenses do adopt Internet banking. They argue that this is to reduce inefficiency by developing distribution channels at lower costs. Similarly, the results show that non-interest expenses increase with Internet adoption because of the related costs.

\section{Methodology}

In what follows, we present our sample and data. Then, a measurement of our variable will be provided. To this end, we summarize, first, all the formulated hypotheses in order to have an overall view of the various proposed relationships. Second, we present the objectives of this study.

2.1. The research question. We can summarize the effort of financial innovation found in a large research question, namely:

What is the consequence of the interaction of forms of financial innovation, if it exists, on the effectiveness of Tunisian banks?

\subsection{The research hypotheses:}

\section{Hypotheses on the relationship between product - process innovation.}

H1: Introduction of product innovation is done simultaneously with process innovation.

H2: Product and process innovation interact with each other.

II. Hypotheses on the impact of the interaction between product and process innovation on banking efficiency.

H3: The interaction between the two types of innovation leads to a high level of banking efficiency.

H 3.1: The interaction between the two types of innovation leads to a high level of bank profitability.

H 3.2: The interaction between the two types of innovation leads to a high level of market share.

H 3.3: The interaction between the two types of innovation leads to a high level of market value.

$H$ 3.4: The interaction between the two types of innovation leads to a low level of bad debts.

2.3. Objectives and expected contributions. In this study, although certain aspects of our problems have

\footnotetext{
${ }^{3}$ To our knowledge, this has been demonstrated by the authors, only for process innovation (internet and web banking).
} 
been previously treated separately, others are examined for the first time. Thus, studying the Tunisian context enables us to, first, test some hypotheses not yet validated by previous studies, and, second, to determine the nature of the interaction between the two types of financial innovation and the impact of this relationship, if any, on bank performance. This last part gives our study a fairly exploratory outlook.

\section{Sample and data}

3.1. Sample. The recent deregulation of the Tunisian banking industry, under the scope of financial liberalization initiated since 1986-1987, has led to increased competition and motivated banks to use new technologies in their production and distribution processes and diversify their range of offered products and services in order to gain a competitive advantage (Mabrouk and Mamoghli, 2010).

3.2. Data. We examine a sample of 10 retail banks, and data that cover the 1985 to 2010 period. Observations retained differ depending on the measurement used. We have a panel data of 260 observations. Also, two questionnaires were administered. The first was addressed to banking experts and the second to banking managers affiliated with the banks in the sample.

\section{List of financial innovations}

The targeted innovations include 17 classic and unconventional intermediation product innovations, and 8 process innovations.

Table 1. List of product and process innovations

\begin{tabular}{|l|l|}
\hline \multicolumn{1}{|c|}{ Product innovations } & \multicolumn{1}{|c|}{ Process innovations } \\
\hline Loans & Electronic payment services \\
\hline Lease credit & Magnetic strip card (debit) \\
\hline Express credit & $\begin{array}{l}\text { Magnetic strip card (debit and ATM } \\
\text { card) }\end{array}$ \\
\hline Auto loan & $\begin{array}{l}\text { Magnetic strip card (ATM and credit } \\
\text { card) }\end{array}$ \\
\hline Flexible interest rate mortgage & Automatic cash dispenser \\
\hline $\begin{array}{l}\text { Line of credit (up to 3 times the sum in } \\
\text { savings) }\end{array}$ & Automatic teller machine \\
\hline Child savings plan loan & Electronic payment terminal \\
\hline Investments & Risk assessment system \\
\hline Certificates of deposit' & \\
\hline Foreign currency deposits & \\
\hline Investment account & \\
\hline $\begin{array}{l}\text { Bond open-ended investment } \\
\text { company }\end{array}$ & \\
\hline Currency exchange & \\
\hline Transfer of funds & \\
\hline Forward cover & \\
\hline Telematic products & \\
\hline Telephone banking (voice server) & \\
\hline Fax banking & \\
\hline SMS banking & \\
\hline $\begin{array}{l}\text { Net banking (account access and } \\
\text { consultation of operations on the } \\
\text { account) }\end{array}$ & \\
\hline
\end{tabular}

Magnetic strip card (business card with special privileges)

Note: This is a short or long-term negotiable security issued by the bank for a specific term. The subscriber may re-sell the bond at any time on the secondary market.

4.1. Estimation technique: testing our assumptions is made in two steps. First, two successive surveys were conducted, one with banking experts and the other with the Tunisian banks of our sample. The second component of our methodology uses panel techniques.

Before we move to the obtained results, we prefer to start with some descriptive statistics to highlight the dynamics of financial innovation in the Tunisian banking industry.

\section{Descriptive statistics}

Product and process innovations affect each other and are adopted either successively or jointly (Batiz-Lazo and Woldesenbet, 2006; Walker, 2004). Indeed, on the one hand, one can lead to the other and, therefore, they may occur in succession. This is almost a lag pattern. On the other hand, one completes the other and can, they thus, occur simultaneously. In this case, this is a synchronous pattern.

Our aim is to test an innovation adoption model in the Tunisian banking context. To this end, we, first, describe correlations ${ }^{4}$ between product and process innovation across the three sub-periods ${ }^{5}$. In the following, we present number of innovations as a measure of adoption degree ${ }^{6}$.

We found that the correlation between adoption of product innovation, during the first period, and the process innovation, during the second period, is smaller in absolute value than correlation of the opposite phenomenon (-0.2712 against -0.4811). Similarly, correlation between adoption of product innovation, during the $2^{\text {nd }}$ period, and process innovation, during the $3^{\text {rd }}$ period, is lower in absolute value than correlation of the opposite phenomenon (0.073 against 0.6721). Moreover, correlation between adoption of process innovation $\left(2^{\text {nd }}\right.$ period $)$ and product innovation $\left(3^{\text {rd }}\right.$ period $)$ is $0.6721(\mathrm{p}<0.05)$. This may indicate that a priori banks follow a lag pattern in the adoption of process-product innovation.

Then, Spearman test ${ }^{7}$ is used to better shed light on which of the two types of innovation occurs first.

${ }^{4}$ For example, compare the correlation between the level of adoption of products (period 1) - degree of adoption of processes (period 2) the correlation between the degree of adoption of processes (period 1) degree of adoption of products (period 2).

${ }^{5}$ 1987-1994, 1995-2002 and 2003-2010.

${ }^{6}$ Both measures reflecting the degree of adoption of innovation led to the same results.

7 The Spearman test is a variable ranking test. It tests whether two variables are independent. These can be coded, for example, from highest to lowest, from best to worst or from first to last. Spearman rho takes values between -1 and 1 . In our context, a value of 1 would indicate that both types of innovation occurring within the rank of the mentioned lag. However, a value of -1 means that it is the opposite phenomenon which occurs with a lag. A rho $=0$ means independence of both types of innovation. 
Table 2. Correlation matrix

\begin{tabular}{|l|c|c|c|c|c|c|c|c|}
\hline \multicolumn{1}{|c|}{ Variables } & Mean & Std. dev & 1 & 2 & 3 & 4 & 5 & 6 \\
\hline $\begin{array}{l}\text { Inv. produit } \\
\text { Période 1 }\end{array}$ & 1.5 & 0.9718 & 1.00 & & & & & \\
\hline $\begin{array}{l}\text { Inv. produit } \\
\text { Période 2 }\end{array}$ & 4.9 & 2.6853 & -0.5322 & 1.00 & & & & \\
\hline $\begin{array}{l}\text { Inv. produit } \\
\text { Période 3 }\end{array}$ & 6.2 & 2.0976 & -0.2180 & $-0.5681^{*}$ & 1.00 & & & \\
\hline $\begin{array}{l}\text { Inv. processus } \\
\text { Période 1 }\end{array}$ & 1.8 & 1.1352 & -0.5189 & -0.4811 & 0.4386 & 1.00 & & \\
\hline $\begin{array}{l}\text { Inv. processus } \\
\text { Période 2 }\end{array}$ & 3.2 & 1.6865 & -0.2712 & $0.8390^{* *}$ & $-0.6721^{* *}$ & $-0.5571^{*}$ & 1.00 & -0.1962 \\
\hline $\begin{array}{l}\text { Inv. processus } \\
\text { Période 3 }\end{array}$ & 4.2 & 1.8135 & -0.3783 & 0.0730 & $0.8007^{* *}$ & -0.0863 & 1.00 \\
\hline
\end{tabular}

Note: $* * * * *$ and $*$ indicate significance at the $1 \%, 5 \%$ and $10 \%$ levels, respectively.

Table 3. Spearman rho test between degrees of adoption of product and process innovation

\begin{tabular}{|l|c|c|c|}
\hline \multirow{2}{*}{ Product innovation } & \multicolumn{2}{|c|}{ Process innovation } \\
\cline { 2 - 4 } & Period 1 & $\begin{array}{c}\text { Period 2 } \\
1995-2002\end{array}$ & $2003-2010$ \\
\hline Period 1 & $1987-1994$ & -0.2487 & -0.4361 \\
1987-1994 & -0.4768 & $(0.4884)$ & $(0.2077)$ \\
\hline Period 2 & $(0.1396)$ & $0.9400^{* * *}$ & 0.2445 \\
1995-2002 & $-0.5434^{*}$ & $(0.0011)$ & $(0.4959)$ \\
\hline Period 3 & $(0.0910)$ & $-0.6507^{*}$ & $0.8902^{+* *}$ \\
2003-2010 & 0.3701 & $(0.0702)$ & $(0.0029)$ \\
\hline
\end{tabular}

For each case, rho and $p$-value are displayed.

Note: $* * * * *$ and $*$ indicate significance at the $1 \%, 5 \%$ and $10 \%$ levels, respectively.

As we mentioned above, there is an agreement that product and process innovation need to be adopted together. Therefore, we sought to determine this adoption model on the banks of our sample. Otherwise, we would like to determine whether both types of innovation occur successively, or one complements the other or both are adopted simultaneously. For this, we used the Spearman rho test.

The test indicates that correlation between adoption of process innovation (at a time) and product innovation (during another period) rule out the possibility of a lag pattern, i.e., there is a delay between the adoption of each type of innovation. This fits a synchronous pattern.

Moreover, probably, Tunisian banks have begun to see the importance or the need for the simultaneous adoption of two types of financial innovation since 1995 to improve their poor performance.

\section{The empirical study}

6.1. Model [I] specification. The model below is constructed to test hypotheses H1 and H2. It captures the interactive relationship between the two types of financial innovation and its impact on bank performance.
The [I] system:

$\left\{\begin{array}{l}I V P D_{i, t}=\lambda_{i 1} I V P C_{i, t}+\gamma_{i 1} P R F_{i, t}+\theta_{i 1} Z_{i, t 1}+ \\ +\eta_{1} Y_{t 1}+C_{i 1}+v_{i, t 1}\end{array}\right.$

$\left\{\begin{array}{l}I V P C_{i, t}=\lambda_{i 2} I V P D_{i, t}+\gamma_{i 2}^{\prime} P R F_{i, t}+\theta_{i 2} Z_{i, t 1}+\eta_{2} Y_{t 1}+ \\ +C_{i 2}+v_{i, t 2}\end{array}\right.$

$$
\begin{aligned}
& P R F_{i, t}=\lambda_{i 3} I V P D_{i, t} \times I V P C_{i, t}+\lambda_{i 4} I V P D_{i, t}+\lambda_{i 5} I V P C_{i, t}+ \\
& +\theta_{i 3}^{\prime} Z_{i, t 2}+\eta_{3} Y_{t 2}+C_{i 3}+v_{i, t 3} .
\end{aligned}
$$

In the first equation of the [I] system, we regress product innovation on process innovation, performance and the variables representing the environmental and organizational context of banks. In the second equation, we regress process innovation on product innovation, performance and the variables representing the environmental and organizational context of banks. In the third equation, we regress bank performance on the relationship between the two types of financial innovation, product innovation, process innovation and on a set of control variables, including variables representing banks' characteristics, banking industry and the macroeconomic conditions. 
With:

$$
\begin{aligned}
& I V P D_{i, t}=\left(N I N V_{i, t 1}\right) \\
& I V P C_{i, t}=\left(N I N V_{i, t 2}\right) \\
& Z_{i, t 1}=\left(D I V_{i, t}, P U B_{i, t}, E T R_{i, t}, T_{i, t}, R F_{i, t}\right)_{(1,5)} \\
& \theta_{i 1}=\left(\theta_{1, i 1}, \theta_{2, i 1}, \theta_{3, i 1}, \theta_{4, i 1}, \theta_{5, i 1}\right)_{(1,5)} \\
& \theta_{i 2}=\left(\theta_{1, i 2}, \theta_{2, i 2}, \theta_{3, i 2}, \theta_{4, i 2}, \theta_{5, i 2}\right)_{(1,5)} \\
& Y_{t 1}=\left(I H H D_{t}\right)_{(1,1)} \\
& P R F_{i, t}=\left(R O A_{i, t}, R O E_{i, t}, P M C_{i, t}, P M D_{i, t}, R C R D_{i, t}, M T B_{i, t}\right) \\
& Z_{i, t 2}=\left(D E P_{i, t}, C R D_{i, t}\right)_{(1,2)} \\
& \theta_{i 3}=\left(\theta_{1 i 3}, \theta_{2, i 3}\right)_{(1,2)} \\
& Y_{t 2}=\left(I H H A_{t}, T F L_{t}, S B C_{t}\right)_{(1,3)} \\
& \eta_{3}=\left(\eta_{1,3}, \eta_{2,3}, \eta_{3,3}\right)_{(1,3)} \\
& v_{i, t 1}, v_{i, t 2}, v_{i, t 3} v_{i, t 4} \text { sont les termes d'erreurs. } c_{i 1}, c_{i 2}, c_{i 3} \text { et } c_{i 4} \text { sont les effets inobservables. }
\end{aligned}
$$

In order to determine the interaction effect, we included the impact of each product and process innovation in the third equation. The aim is to neutralize their direct effects on performance, because, otherwise, their interaction term does not reflect the interaction effect, but it will also include their respective direct effects. Indeed, in general, models with interaction effects should also include the direct effects of the interaction of variables separately in terms, even if the direct effects are no longer significant once all are included in the same equation (Jaccard et al., 2003; Jaccard and Wan, 1996).

6.2. The control function approach. These estimators are also obtained in two steps. Consider, for example, equation (1) of the [I] system. The first instrumental step consists in regressing the endogenous variables $P R F_{i, t}$ and $I V P C_{i, t}$, respectively, on the exogenous variables in equation (1) and instruments present, respectively, in equation (2) and equation (3), then, extract the two fitted values of error terms. Then, second, we regress $I V P D_{i, t}$ on the exogenous variables $\left(Z i, t_{1}, Y t_{1}\right)$ of equation (1), $I V P C_{i, t}, P R F_{i, t}$ and both fitted values of error terms. This will control the endogeneity of the endogenous variables $I V P C_{i, t}$ and $P R F_{i, t}$ in the original equation (1). However, for the endogenous variables $I V P C_{i, t}$ in equation (1) and $I V P D_{i, t}$ in equation (2), this is an extreme case where equations (1) and (2) include exactly the same exogenous variables. This involves looking for instruments outside the [I] system.

\section{Choice of instruments:}

consider equation (1) of the [I] system:

$$
\begin{aligned}
& I V P D_{i, t}=\lambda_{i 1} I V P C_{i, t}+\dot{\gamma}_{i 1}^{\prime} P R F_{i, t}+\theta_{i 1}^{\prime} \cdot Z_{i, t 1}+\eta_{1} \cdot Y_{t 1} \\
& +c_{i 1}+v_{i, t 1 .}
\end{aligned}
$$

To ensure a valid instrumentation of $I V P C_{i, t}$, the control function approach technique assumes a certain correlation (at a level of significance not greater than $5 \%$ ) between the instruments $Z_{j}$ and $I V P C_{i, t}$ to ensure consistency. We also assume that the instruments satisfy the condition: $\operatorname{cov}\left(Z_{j}, v_{i, t 1}\right)=0, j=$ $1, \ldots, k$. Instrumentation of $I V P C_{i, t}$ is the same as that of $I V P D_{i, t}$ in equation (2).

We propose to instrument $I V P C_{i, t}$ and $I V P D_{i, t}$ by their respective lags $(t-1)$ and $(t-2)$. Indeed, Roberts and Amit (2003) suggest that innovative activity of a bank is a function of its history in financial innovation. The results show that these two lagged variables have a significant impact on Tunisian banks' adoption of financial innovation, $I V P D_{i, \mathrm{t}}$ and $I V P C_{i, t}$ (at the $1 \%$ and $5 \%$ levels). Thus, during this first stage of estimation, we obtain a dynamic panel. In addition, the choice of the lag date is a bit tricky, because $I V P C_{i, t}$ and $I V P D_{i, t}$ each represents the number of process and product innovations, respectively, introduced over the past five years ${ }^{8}$.

\section{Tests of validity of instruments:}

the Sargan and Hansen over-identification tests are used to check the validity of the instruments. Moreover, we opted for the two instrumental variables $I V P C_{i, t}$ and $I V P D_{i, t}$ so that equations (1) and (2) are identified as required by the GMM method ${ }^{9}$.

6.3. Description of the measures. NINV represents the number of product or process innovations adopted by the bank in the past five years. In other words, innovation is a time variable reflecting a cumulative five-year process. We believe that this period is long enough to show some variability in the adoption of innovation in product and process, and to observe their impact on bank performance. Bank performance in terms of efficiency is opera-

\footnotetext{
${ }^{8}$ The generalized method of moments GMM takes into account the endogeneity problems, issued also from the possibility of simultaneity between the endogenous variable and its instruments.

${ }^{9}$ We also checked for the absence of multicollinearity in this first estimation step.
} 
tionalized through measures of profitability, market value, market share and risk. Performance indicators, mainly derived from De Young et al. (2007), Mohieldin and Nasr (2007), Iannotta et al. (2007), Dow (2007), Furst et al. (2002), are measured in terms of variation in performance between year $t$ and $(t-5)$.

The literature review examined a variety of independent variables. We selected a limited number of variables, because our main focus is to test the hypotheses on the relationship between the two types of financial innovation and the impact of the latter on banking efficiency.

In this study, measures of independent variables of financial innovation are tricky because its adoption is a cumulative process over five years, which leads to a simultaneity hypothesis ${ }^{10}$. Thus, like Herrera and Minetti (2007), we take the average of the values of the independent variables between years $(t$ $5)$ and $(t-1)$, against the values of the independent variables proceeding each period, i.e., in $(t-5)^{11}$.

Several authors, such as Dow (2007), assume a reverse causality between the determinants of adoption of financial innovation and these latter. To circumvent any potential simultaneity bias, Furst et al. (2002) ensured that the independent variables, measuring bank characteristics, precede adoption of Internet banking.

Table 4. Summary of the variables

\begin{tabular}{|l|l|}
\hline \multicolumn{1}{|c|}{ Variable } & \multicolumn{1}{c|}{ Definition } \\
\hline $\begin{array}{l}\text { Financial innovation (total count of innovative acts during the previous five } \\
\text { years) }\end{array}$ & $\begin{array}{l}\text { The number of innovations adopted } \\
\text { during the previous five years for } \\
\text { which the bank was the first mover in } \\
\text { product innovation. }\end{array}$ \\
\hline FIRST (process) & $\begin{array}{l}\text { The number of innovations adopted } \\
\text { during the previous five years for } \\
\text { which the bank was the first mover in } \\
\text { process innovation. }\end{array}$ \\
\hline IMIT (product) & $\begin{array}{l}\text { The number of innovations adopted } \\
\text { during the previous five years for } \\
\text { which the bank was the imitator in } \\
\text { product innovation. }\end{array}$ \\
\hline IMIT (process) & $\begin{array}{l}\text { The number of innovations adopted } \\
\text { during the previous five years for } \\
\text { which the bank was the imitator in } \\
\text { process innovation. }\end{array}$ \\
\hline Performance $(\Delta$ between $t$ and (t-5))
\end{tabular}

\footnotetext{
${ }^{10}$ Indeed, the choice of the year, belonging to the interval $[\mathrm{t}-4 ; \mathrm{t}]$, the value of the independent variable may coincide with the year of the adoption of certain innovation.

${ }^{11} \mathrm{We}$ believe that such values are restrictive in order to circumvent the endogeneity problem. This is achieved by failing to take into account the kind of different values obtained during each period of five years and may, certainly, influence the cumulative process of financial innovation.
}

\begin{tabular}{|l|l|}
\hline & credit granted by all banks). \\
\hline$\Delta$ PMC & $\Delta$ (bank loans / total loans). \\
\hline$\Delta$ PMD & $\Delta$ (bank deposits / total deposits). \\
\hline$\Delta$ CRDR & $\Delta$ (delinquent loans / total loans). \\
\hline$\Delta$ MTB & $\begin{array}{l}\Delta \text { (market value / book value of the } \\
\text { shares). }\end{array}$ \\
\hline Control variables of financial innovation (average between (t-5) and (t-1)) \\
\hline IHHD & $\begin{array}{l}\text { The average of Hirshman-Herfindhal } \\
\text { index of concentration of bank } \\
\text { deposits. }\end{array}$ \\
\hline DIV & $\begin{array}{l}\text { The average of } D=(1-2 x-1) \text { where } \\
\mathrm{X}=\text { non-interest income / net } \\
\text { operating revenue. }\end{array}$ \\
\hline PUB & $\begin{array}{l}\text { The average percentage of public } \\
\text { share ownership. }\end{array}$ \\
\hline FRG & $\begin{array}{l}\text { The average percentage of foreign } \\
\text { share ownership. }\end{array}$ \\
\hline SIZE & $\begin{array}{l}\text { The logarithm for the average of the } \\
\text { total assets of the bank. }\end{array}$ \\
\hline FR & The average of net profit. \\
\hline $\begin{array}{l}\text { Control variables of performance (average between ( } \mathrm{t}-6 \text { ) et ( } \mathrm{t}-1) \text { ) } \\
\text { SBC balance of payment }\end{array}$ \\
\hline $\begin{array}{l}\text { TFL the average of inflation rate, measured by the average of consumer } \\
\text { goods }\end{array}$ \\
\hline
\end{tabular}

Several authors like De Young et al. (2007), Herrera and Minetti (2007) have examined the effect of competition. Size is used by all the studies on the adoption of innovation in the banking industry (Dow, 2007; De Young et al., 2007; Furst et al., 2002). We measured competition by the logarithm of the average of the total assets of the bank in order to diminish the problem of scale. Diversification was used in the banking industry by several authors (Baele et al., 2007; Leaven and Levine, 2007; Stiroh, 2006), where the D measure takes into account diversity of income ${ }^{12}$. We use percentages of public and foreign participation in the capital of the bank as measures of ownership structure. Net income reflects the ability of the bank to finance these investments and take risks (Fuentelsaz et al., 2003). It provides, as well, banks with funds necessary for the adoption of financial innovation (Furst et al., 2002). Financial resources, FR, are measured by net profit. They provide, as well, banks with funds necessary for the adoption of financial innovation, essentially, process innovation because of the high investment they demand (Furst et al., 2002).

\section{Impact of the interaction between product and process innovation on bank performance}

In what follows, we test the hypothesis that the two types of financial innovation interact with each other and whose interaction leads to high levels of banking efficiency. The latter is operationalized in terms of profitability, market value, market share

\footnotetext{
${ }^{12}$ The $D$ measure takes into account income diversity. It takes values between 0 and 1 and it increases when the degree of diversification of the bank increases.
} 
and risk. The numbers of product and process innovations are adopted as measures.

The aim is to determine the interaction effect of both types of financial innovation on Tunisian banking efficiency. We would like to show that if, for a high level of product (process) innovation, adoption of process (product) innovation leads to an improvement in banking efficiency. In other words, a positive value of the interaction effect term means that the greater is the adoption of product innovation (more positive), the greater is the effect of the adoption of process innovation on bank performance. Similarly, the greater is the adoption of process innovation, the larger (more positive) is the effect of the adoption of product innovation on bank performance ${ }^{13}$.

We found a strong positive relationship between adoption of product and process innovation, with a significant correlation coefficient of 0.23 at the 5\% level. The results also show that product and process innovations are positively correlated, and this in all estimations, suggesting thereby that, for Tunisian banks, the introduction of new products leads to an increase in new processes and vice versa. We found that the separate impacts of each type of innovation on performance (in equation 3) are not significant ${ }^{14}$, except on the risk indicator. Their direct impact on this performance indicator is significant because their interaction effect is not.

As mentioned above, we proposed to instrument the endogenous variables $I V P C_{i, t}$ and $I V P D_{i, t}$ by their respective lags. The choice of lags $(t-1)$ and $(t-2)$ for the endogenous variables $I V P C_{i, t}$ in equation (1) and $I V P D_{i, t}$ in equation (2), decreased the number of observations to 180 observations ${ }^{15}$. Indeed, Roberts and Amit (2003) suggest that an innovative activity of a bank is a function of its history in financial innovation. The results show that these two lagged variables have a significant impact on the adoption of financial innovation, $I V P D_{i, t}$ and $I V P C_{i, t}$ (at the $1 \%$ and $5 \%$ levels) by Tunisian banks. Thus, during this first stage of estimation, we obtain a dynamic panel. Moreover, the choice of the lag date is a bit tricky because $I V P C_{i, t}$ and $I V P D_{i, t}$ each represents the number of process and product innovations, respectively, introduced over the past five years ${ }^{16}$.

The probability of the Sargan test on the validity of the instruments $I V P C_{i, t}$ and $I V P D_{i, t}$, is, respectively, 0.937

\footnotetext{
${ }^{13}$ This interpretation of the interaction term between two continuous variables is provided by Jaccard et al. (2003).

${ }^{14}$ The direct effects of the variables used in the interaction terms are, generally, no longer significant once included with their interaction effect in the same equation (Jaccard et al., 2003).

${ }^{15}$ This enables us to keep a good degree of freedom.

${ }^{16}$ The generalized method of moments GMM takes into account the endogeneity problems, issued also from the possibility of simultaneity between the endogenous variable and its instruments.
}

and 0.957. Furthermore, the Hansen overidentification test ${ }^{17}$ shows probabilities of 0.877 and 0.953 . Thus, referring to both the Sargan and Hansen tests, we cannot reject hypothesis $\mathrm{HO}$ on the validity of instruments.

6.1. Profitability. The results reported in Table 5 show that profitability, in terms of ROA and ROE, significantly stimulates (at the $1 \%$ level) the adoption of the two types of financial innovation. However, their interaction leads to a significant decrease in profitability at the $10 \%$ level. Moreover, we found similar results on the return on assets before tax ratio. Probably, the high cost required to investment in introducing process innovation explains this decrease in profitability.

6.2. Market share. The results in Table 6 below indicate that a high market share motivates the bank to significantly engage in a process innovation at the $10 \%$ level. In return, interaction between product and process innovation provides the bank with a competitive advantage and a significant market share at the $5 \%$ level. In other words, for a high level of adoption of process innovation (product), the adoption of product innovation (process) leads to increased market share. This result is true for both credit and deposits market share.

Market value: The results in Table 7 indicate that high interaction between product and process innovation positively and significantly (at the 5\% level) affects market value. Market of innovative banks is high because adoption of the two types of financial innovation is perceived by the market as a determinant of efficiency and technological progress.

Risk: We found that high levels of bad loans discouraged the adoption of product innovation ${ }^{18}$ (at the $1 \%$ level) and also encouraged the adoption of process innovation $^{19}$ (at the $1 \%$ level). Moreover, the direct effect of each type of innovation on credit risk is significant, where the adoption of product innovation increased the volume of bad debts (at the 5\% level) while developing a risk assessment system helps to reduce credit risk (at the 5\% level).

Table 7 shows that the interaction between the two types of financial innovation has no effect on credit risk ratio. We believe that the positive effect of product innovation is offset by the negative effect of process innovation. This suggests that the development of a risk assessment system by Tunisian banks will bring fruits, helping them to better overcome the problems of adverse selection and moral hazard arising from information asymmetries.

\footnotetext{
${ }^{17}$ The Hansen test is robust to heteroscedasticity.

${ }_{18}^{18}$ A classic intermediation activity.

${ }^{19}$ This is the risk assessment system, supposed to improve the banks' credit quality.
} 
Table 5. Estimation by the control function approach of the interaction effect of the two financial innovation on profitability

\begin{tabular}{|c|c|c|c|c|c|c|}
\hline Independent variables & Product innovation & Process innovation & $\mathrm{ROA}$ & Product innovation & Process innovation & ROE \\
\hline Constant & $\begin{array}{c}10.1616 \\
(1.19)\end{array}$ & $\begin{array}{c}32.1422 \\
(0.70)\end{array}$ & & $\begin{array}{c}42.3857 \\
(1.55)\end{array}$ & $\begin{array}{c}3.3214 \\
(0.14)\end{array}$ & \\
\hline NINV (Inv. Product) & & $\begin{array}{c}0.0149^{+*+*} \\
(2.75)\end{array}$ & & & $\begin{array}{c}0.41101^{*+*} \\
(3.58)\end{array}$ & \\
\hline NINV (Inv. Process) & $\begin{array}{c}0.0494^{* *} \\
(2.18)\end{array}$ & & & $\begin{array}{c}0.3398^{* *} \\
(1.98) \\
\end{array}$ & & \\
\hline Performance & $\begin{array}{c}0.0636^{*+*} \\
(4.94)\end{array}$ & $\begin{array}{c}0.1137^{* *} \\
(6.63)\end{array}$ & & $\begin{array}{c}15.4966 \\
(3.47)\end{array}$ & $\begin{array}{c}12.4955^{*+*} \\
(2.72)\end{array}$ & \\
\hline $\mathrm{IHHD}$ & $\begin{array}{c}-0.0103^{* * *} \\
(-4.82)\end{array}$ & $\begin{array}{c}-0.0103^{*+*} \\
(-2.79)\end{array}$ & & $\begin{array}{c}-0.0373^{+* * *} \\
(-2.69)\end{array}$ & $\begin{array}{c}-0.0069^{* * *} \\
(-2.85)\end{array}$ & \\
\hline DIV & $\begin{array}{c}-2.3726^{* \prime} \\
(-2.51)\end{array}$ & $\begin{array}{c}-1.2909 \\
(-0.31)\end{array}$ & & $\begin{array}{c}-6.75641^{*+} \\
(-2.39)\end{array}$ & $\begin{array}{l}-2.4025 \\
(-1.18)\end{array}$ & \\
\hline PUB & $\begin{array}{l}-0.4001^{*} \\
(-1.12) \\
\end{array}$ & $\begin{array}{l}3.1069 \\
(0.32) \\
\end{array}$ & & $\begin{array}{c}-1.1935^{* *} \\
(-1.99) \\
\end{array}$ & $\begin{array}{c}-0.4433 \\
(-0.78) \\
\end{array}$ & \\
\hline ETR & $\begin{array}{l}0.3407^{*} \\
(1.94)\end{array}$ & $\begin{array}{l}6.0217 \\
(0.31)\end{array}$ & & $\begin{array}{c}2.02773^{\star} \\
(1.77)\end{array}$ & $\begin{array}{c}2.3057^{*} \\
(1.74)\end{array}$ & \\
\hline $\mathrm{T}$ & $\begin{array}{l}0.3103 \\
(0.92) \\
\end{array}$ & $\begin{array}{c}0.6079^{*} \\
(1.89) \\
\end{array}$ & & $\begin{array}{c}-0.83042 \\
(-1.11) \\
\end{array}$ & $\begin{array}{c}0.92594^{* *} \\
(2.53) \\
\end{array}$ & \\
\hline RF & $\begin{array}{c}0.1316^{*} \\
(1.94) \\
\end{array}$ & $\begin{array}{c}0.4818^{*} \\
(1.91) \\
\end{array}$ & & $\begin{array}{c}0.54053^{*} \\
(1.78)\end{array}$ & $\begin{array}{c}0.81028^{*} \\
(1.92)\end{array}$ & \\
\hline Pseudo R ${ }^{2}$ & 0.1091 & 0.0993 & & 0.1121 & 0.0974 & \\
\hline Log pseudolikelihood & -323.2004 & -308.4298 & & -310.4502 & -311.4035 & \\
\hline Constante & & & $\begin{array}{c}-9.3723^{*} \\
(-1.92)\end{array}$ & & & $\begin{array}{c}-0.0572 \\
(-1.52)\end{array}$ \\
\hline Interaction 20 & & & $\begin{array}{l}-0.0479^{*} \\
(-1.83) \\
\end{array}$ & & & $\begin{array}{c}-0.00595^{*} \\
(-1.79) \\
\end{array}$ \\
\hline NINV (Inv. Product) & & & $2.2762(1.05)$ & & & $\begin{array}{c}0.01139 \\
(1.45) \\
\end{array}$ \\
\hline NINV (Inv. Process) & & & $\begin{array}{c}-4.1286 \\
(-1.30) \\
\end{array}$ & & & $\begin{array}{c}-0.0129 \\
(-1.41) \\
\end{array}$ \\
\hline $\mathrm{IHHA}$ & & & $\begin{array}{c}-0.05988^{* *+} \\
(-2.86)\end{array}$ & & & $\begin{array}{c}0.0005^{+* *} \\
(2.99)\end{array}$ \\
\hline DEP & & & $\begin{array}{c}-27.9961^{*} \\
(-1.75) \\
\end{array}$ & & & $\begin{array}{l}-0.1227 \\
(-1.12) \\
\end{array}$ \\
\hline CRD & & & $\begin{array}{l}-6.8664 \\
(-0.53) \\
\end{array}$ & & & $\begin{array}{c}-0.0919 \\
(-1.09) \\
\end{array}$ \\
\hline TFL & & & $\begin{array}{c}-157.5684 \\
(-1.62) \\
\end{array}$ & & & $\begin{array}{c}-0.7532 \\
(-1.18) \\
\end{array}$ \\
\hline SBC & & & $\begin{array}{c}-0.0547^{*} \\
(-1.84)\end{array}$ & & & $\begin{array}{c}-0.0547^{* *} \\
(-1.99)\end{array}$ \\
\hline Adjusted R2 & & & 0.1371 & & & 0.1228 \\
\hline
\end{tabular}

Table 6. Estimation by the control function approach of the interaction effect of the two types of financial innovation on market share (total sample)

\begin{tabular}{|c|c|c|c|c|c|c|}
\hline Independent variables & Product innovation & Process innovation & PMC & Product innovation & Process innovation & PMD \\
\hline Constant & $\begin{array}{c}29.33002 \\
(1.11)\end{array}$ & $\begin{array}{c}-9.06784 \\
(-0.43)\end{array}$ & & $\begin{array}{c}34.34785 \\
(0.95)\end{array}$ & $\begin{array}{c}25.90524 \\
(0.71)\end{array}$ & \\
\hline NINV (Inv. Product) & & $\begin{array}{c}0.55726^{\star \star \star} \\
(3.22)\end{array}$ & & & $\begin{array}{c}0.4893^{\star \star \star} \\
(2.73)\end{array}$ & \\
\hline NINV (Inv. Process) & $\begin{array}{c}0.48913^{* *} \\
(2.57)\end{array}$ & & & $\begin{array}{c}0.47928^{* *} \\
(2.24)\end{array}$ & & \\
\hline Performance & $\begin{array}{c}4.0929^{*} \\
(1.82) \\
\end{array}$ & $\begin{array}{c}2.1136^{*} \\
(1.70) \\
\end{array}$ & & $\begin{array}{c}7.3079^{*} \\
(1.75) \\
\end{array}$ & $\begin{array}{c}4.5060 \\
(1.22) \\
\end{array}$ & \\
\hline $\mathrm{IHHD}$ & $\begin{array}{c}-0.0206^{\star \star *} \\
(-2.74)\end{array}$ & $\begin{array}{c}-0.0093^{\star \star \star} \\
(-2.87)\end{array}$ & & $\begin{array}{c}-0.0219^{* * *} \\
(-2.73)\end{array}$ & $\begin{array}{c}-0.0014^{\star \star \star} \\
(-2.92)\end{array}$ & \\
\hline DIV & $\begin{array}{c}-1.5324^{* * *} \\
(-3.17)\end{array}$ & $\begin{array}{c}-2.03068 \\
(-1.01)\end{array}$ & & $\begin{array}{c}-1.8735^{* *} \\
(-2.09)\end{array}$ & $\begin{array}{c}-0.9173 \\
(-0.24)\end{array}$ & \\
\hline
\end{tabular}

\footnotetext{
${ }^{20}$ Product innovation * process innovation.
} 
Table 6 (cont.). Estimation by the control function approach of the interaction effect of the two types of financial innovations on market share (total sample)

\begin{tabular}{|c|c|c|c|c|c|c|}
\hline Independent variables & Product innovation & Process innovation & PMC & Product innovation & Process innovation & PMD \\
\hline PUB & $\begin{array}{c}-1.4106^{*} \\
(-1.95)\end{array}$ & $\begin{array}{l}-0.4121 \\
(-0.92)\end{array}$ & & $\begin{array}{c}-1.4773^{*} \\
(-1.88)\end{array}$ & $\begin{array}{l}-0.0076 \\
(-0.15)\end{array}$ & \\
\hline ETR & $\begin{array}{c}0.5386 \\
(1.99)\end{array}$ & $\begin{array}{c}0.2985^{*} \\
(1.93)\end{array}$ & & $\begin{array}{c}0.6555^{*} \\
(1.84)\end{array}$ & $\begin{array}{c}0.7801^{*} \\
(2.84)\end{array}$ & \\
\hline $\mathrm{T}$ & $\begin{array}{c}-0.2631 \\
(-1.22)\end{array}$ & $\begin{array}{c}0.4055^{*} \\
(1.98)\end{array}$ & & $\begin{array}{c}-0.4203 \\
(-1.24)\end{array}$ & $\begin{array}{c}0.99092^{*} \\
(1.73)\end{array}$ & \\
\hline RF & $\begin{array}{c}0.30155^{*} \\
(1.83)\end{array}$ & $\begin{array}{c}0.57234^{*} \\
(1.96)\end{array}$ & & $\begin{array}{c}0.30325^{*} \\
(1.88)\end{array}$ & $\begin{array}{c}0.16417^{*} \\
(1.91)\end{array}$ & \\
\hline Pseudo $\mathrm{R}^{2}$ & 0.1131 & 0.1053 & & 0.1147 & 0.1084 & \\
\hline Log pseudolikelihood & -234.2004 & -255.4231 & & -239.5731 & -275.0392 & \\
\hline Constant & & & $\begin{array}{c}-0.0027 \\
(-0.86)\end{array}$ & & & $\begin{array}{l}0.0021 \\
(1.02)\end{array}$ \\
\hline Interaction & & & $\begin{array}{c}0.0002^{* *} \\
(2.02)\end{array}$ & & & $\begin{array}{c}0.0003^{* *} \\
(2.27)\end{array}$ \\
\hline NINV (Inv. Product) & & & $\begin{array}{c}0.0054 \\
(1.29)\end{array}$ & & & $\begin{array}{l}0.0005 \\
(1.52)\end{array}$ \\
\hline NINV (Inv. Process) & & & $\begin{array}{c}0.0033 \\
(1.34)\end{array}$ & & & $\begin{array}{c}0.0007 \\
(1.29)\end{array}$ \\
\hline IHHA & & & $\begin{array}{c}0.00001^{\text {tot }} \\
(3.47)\end{array}$ & & & $\begin{array}{c}9.19 \mathrm{e}-06 \\
(2.99)\end{array}$ \\
\hline DEP & & & $\begin{array}{c}-0.06687^{* *} \\
(-3.36)\end{array}$ & & & $\begin{array}{c}0.0307^{+*} \\
(2.82)\end{array}$ \\
\hline CRD & & & $\begin{array}{c}0.13194^{+*} \\
(5.33)\end{array}$ & & & $\begin{array}{c}-0.0089 \\
(-0.59)\end{array}$ \\
\hline TFL & & & $\begin{array}{c}0.0743 \\
(0.36) \\
\end{array}$ & & & $\begin{array}{l}0.0315 \\
(0.24) \\
\end{array}$ \\
\hline SBC & & & $\begin{array}{c}0.00002 \\
(0.88)\end{array}$ & & & $\begin{array}{c}0.00001 \\
(-1.28) \\
\end{array}$ \\
\hline Adjusted $R^{2}$ & & & 0.2033 & & & 0.1834 \\
\hline
\end{tabular}

Table 7. Estimation by the control function approach of the interaction effect of the two types of financial innovation on market value and credit risk (total sample)

\begin{tabular}{|c|c|c|c|c|c|c|}
\hline Independent variables & $\begin{array}{c}\text { Product } \\
\text { innovation }\end{array}$ & Process innovation & MTB & Product innovation & Process innovation & RCRD \\
\hline Constant & $\begin{array}{c}-9.8032 \\
(-1.00)\end{array}$ & $\begin{array}{c}15.1987 \\
(0.33)\end{array}$ & & $\begin{array}{c}79.4817^{+1+k} \\
(2.95)\end{array}$ & $\begin{array}{c}-89.8862^{+1+} \\
(-3.27)\end{array}$ & \\
\hline NINV (Inv. Product) & & $\begin{array}{c}0.0357^{\text {t+1 }} \\
(2.68)\end{array}$ & & & $\begin{array}{c}1.1359^{* * *} \\
(5.34)\end{array}$ & \\
\hline NINV (Inv. Process) & $\begin{array}{c}0.0527^{* *} \\
(2.48)\end{array}$ & & & $\begin{array}{c}0.57625^{* *} \\
(2.02)\end{array}$ & & \\
\hline Performance & $\begin{array}{l}-0.0996 \\
(-0.68)\end{array}$ & $\begin{array}{l}0.1672 \\
(1.37)\end{array}$ & & $\begin{array}{c}-31.5812^{* * *} \\
(-3.57)\end{array}$ & $\begin{array}{c}37.8495^{\star * *} \\
(4.05)\end{array}$ & \\
\hline IHHD & $\begin{array}{c}-0.0022^{* *+} \\
(-3.18)\end{array}$ & $\begin{array}{c}-0.0106^{*+*} \\
(-3.00)\end{array}$ & & $\begin{array}{c}-0.0656^{\text {t*t }} \\
(-4.57)\end{array}$ & $\begin{array}{c}-0.0761^{\text {tht }} \\
(-4.23)\end{array}$ & \\
\hline DIV & $\begin{array}{c}-2.3559^{* *+} \\
(-2.70)\end{array}$ & $\begin{array}{l}-2.7321 \\
(-0.67)\end{array}$ & & $\begin{array}{c}-6.7004^{*+} \\
(-2.50)\end{array}$ & $\begin{array}{l}-8.4787 \\
(-1.01)\end{array}$ & \\
\hline PUB & $\begin{array}{c}-0.9506^{*+} \\
(-2.52)\end{array}$ & $\begin{array}{c}5.8172 \\
(0.60) \\
\end{array}$ & & $\begin{array}{c}-2.2312^{*} \\
(-1.84)\end{array}$ & $\begin{array}{c}2.40841 \\
(1.27)\end{array}$ & \\
\hline ETR & $\begin{array}{c}1.0354^{*} \\
(1.82)\end{array}$ & $\begin{array}{c}12.3395^{\star} \\
(1.90)\end{array}$ & & $\begin{array}{c}2.39714^{\star} \\
(1.89)\end{array}$ & $\begin{array}{c}2.90856^{*} \\
(1.95)\end{array}$ & \\
\hline $\mathrm{T}$ & $\begin{array}{l}-0.4005 \\
(-1.19)\end{array}$ & $\begin{array}{c}1.2192^{*} \\
(1.77)\end{array}$ & & $\begin{array}{c}0.27173 \\
(1.22)\end{array}$ & $\begin{array}{c}0.41278^{* *} \\
(2.03)\end{array}$ & \\
\hline RF & $\begin{array}{c}0.0936^{*} \\
(1.91)\end{array}$ & $\begin{array}{c}0.2378^{*} \\
(1.89)\end{array}$ & & $\begin{array}{c}0.21858^{*} \\
(1.87)\end{array}$ & $\begin{array}{c}0.27907^{*} \\
(1.94)\end{array}$ & \\
\hline Pseudo $\mathrm{R}^{2}$ & 0.1079 & 0.0917 & & 0.1005 & 0.1084 & \\
\hline Log pseudolikelihood & -323.6239 & -307.6081 & & -294.0923 & -245.2971 & \\
\hline Constant & & & $\begin{array}{c}4.7404^{\text {tat }} \\
(4.43)\end{array}$ & & & $\begin{array}{c}0.0193 \\
(0.97)\end{array}$ \\
\hline Interaction & & & $\begin{array}{c}0.0564^{* *} \\
(1.99)\end{array}$ & & & $\begin{array}{l}0.0016 \\
(1.11)\end{array}$ \\
\hline
\end{tabular}


Table 7 (cont.). Estimation by the control function approach of the interaction effect of the two types of financial innovation on market value and credit risk (total sample)

\begin{tabular}{|c|c|c|c|c|c|c|}
\hline Independent variables & $\begin{array}{c}\text { Product } \\
\text { innovation }\end{array}$ & Process innovation & MTB & Product innovation & Process innovation & RCRD \\
\hline NINV (Inv. Product) & & & $\begin{array}{l}0.6917 \\
(1.29)\end{array}$ & & & $\begin{array}{c}0.0159^{* *} \\
(1.98)\end{array}$ \\
\hline NINV (Inv. Process) & & & $\begin{array}{l}1.5225 \\
(1.18)\end{array}$ & & & $\begin{array}{c}-0.0272^{* *} \\
(-2.38)\end{array}$ \\
\hline $\mathrm{IHHA}$ & & & $\begin{array}{c}-0.0075^{*} \\
(-1.75) \\
\end{array}$ & & & $\begin{array}{c}0.0004^{*} \\
(2.40) \\
\end{array}$ \\
\hline DEP & & & $\begin{array}{c}-8.5691^{\text {tot }} \\
(-2.96)\end{array}$ & & & $\begin{array}{c}-0.07962 \\
(-0.55)\end{array}$ \\
\hline CRD & & & $\begin{array}{c}5.4763^{*} \\
(2.03)\end{array}$ & & & $\begin{array}{c}-0.00251 \\
(-0.02)\end{array}$ \\
\hline TFL & & & $\begin{array}{c}-25.7556 \\
(-1.06)\end{array}$ & & & $\begin{array}{c}0.44002 \\
(0.31)\end{array}$ \\
\hline SBC & & & $\begin{array}{c}-0.0042 \\
(-0.95)\end{array}$ & & & $\begin{array}{c}0.0039^{+*} \\
(2.31)\end{array}$ \\
\hline Adjusted $R^{2}$ & & & 0.2704 & & & 0.2554 \\
\hline
\end{tabular}

\section{The results}

7.1. The relationship between the two types of financial innovation. The results of the descriptive statistics rather converge towards the simultaneous adoption of the two types of financial innovation during the 1995 to 2010 period, which points to synchronous adoption pattern. H.1 hypothesis is not confirmed because it is only validated during the 19952010 period. Moreover, the results confirm the hypothesis H.2: product and process innovation interact with one another.

7.2. Impact of the interaction of the two types of innovation on banking efficiency. We found that the interaction of the two types of financial innovation adopted by Tunisian banks improves their efficiency only in market share and market value, thus, confirming only H3.2 and H3.3. However, the interaction effect of product and process innovation reduces profitability (at the $10 \%$ level). We conclude that this is, probably, explained by the fact that incomes of Tunisian banks are unable to cover the higher costs of investing in new technologies. Specifically, interaction between the two types of financial innovation has no significant impact on credit risk. Thus, hypothesis $\mathrm{H} 3$ is not, ultimately, confirmed.

7.3. Robustness of the results. The results allowed us to identify the influential determinants of financial innovation. This is explained by the choice of relevant internal and external factors of banks which show the specificities of the Tunisian banking industry. More specifically, determinants of financial innovation have kept the same sign and, at least, the same significance in equations (1) and (2) of the proposed model. Moreover, dividing the study period into two periods to consider accounting changes the banks' financial statements ${ }^{21}$ consolidate the robustness of the results.

\footnotetext{
${ }^{21}$ The new standard is applied to financial statements of fiscal years beginning on 1 January 1997. Thus, the first fiscal year starts from December 31, 1997.
}

However, we note that the effect of financial innovation on bank performance during first period [1991, 1997] is very small or insignificant. It becomes significant at the 5\% and $1 \%$ levels during the second period $[1998,2010]$. This can be explained by the fact that maturation of financial innovation was gradually reached in 1998. In other words, with a perspective of openness to financial services, Tunisian banks looking for a better performance, began to better understand how to achieve this objective, from that date. Thus, they seem to better control the introduction of new technologies in managing their production and distribution systems and leveraging more knowledge in their main intermediation activity ${ }^{22}$ and in the market.

7.4. Contributions. In addition to bringing some light to understanding the relationship between innovation and performance, this study used a joint empirical modeling of variables defining environmental and organizational context, financial innovation and bank performance.

Furthermore, under this empirical modeling, if some aspects of our problem have already been previously treated separately, others are examined for the first time. Thus, studying the Tunisian case, we tried, first, to confirm or refute some previous results and, second, to test hypotheses not yet validated by previous studies, which gives this study on the interaction of the two types of financial innovation and its impact on bank performance a fairly exploratory outlook.

\section{Conclusion}

We examined the interaction between the two types of financial innovation and its impact on banking efficiency. We found that this interaction led to a significant decrease in profitability at the $10 \%$ level and provides the bank with a significant market share. Moreover, high interaction of product and process

\footnotetext{
${ }^{22}$ Through better job quality which is reflected by a slowdown in the volume of non-performing loans.
} 
innovation positively and significantly (at the 5\% level) affects market value where the market perceives financial innovation as a determining factor of efficiency and technological progress. However, the interaction between the two types of financial innovation has no effect on credit risk ratio. From these results, we can conclude that Tunisian banks have not yet managed to achieve any efficiency targets, through the joint adoption of product and process innovation. This efficiency is achieved only in terms of market share and value. Thus, financial innovation is a value creation instrument for Tunisian banks. Still, the development of a risk assessment system seems essential to start bringing some benefits. Thus, we recommend that Tunisian banks improve, on the one hand, their profitability by optimizing the proposed telematics products to stimulate online banking. On the other hand, attempt to optimize the risk assessment system. Once the Tunisian banking system exceeds enough the revolution fallout, it would be interesting to pursue and explore again the dynamics of financial innovation.

\section{References}

1. Baele, L., De Jonghe, O. and Vennet, R.V. (2007). Does the stock market value bank diversification? Journal of Banking and Finance, 31 (7), pp. 1999-2023.

2. Batiz-Lazo, B. and Woldesenbet, K. (2006). The dynamics of product and process innovation in UK banking, International Journal of Financial Services Management, 1 (4), pp. 400-421.

3. Batiz-Lazo, B. and Wood, D. (2003). Strategy competition and diversification in European and Mexican banking, International Journal of Bank Marketing, 21 (4), pp. 202-216.

4. Betz, F. (2016). International Grid of Capital Flows: Innovation, Crisis, and Off-shore Banking. Stability in International Finance: Applications of Price Disequilibrium Theory, Springer Briefs in Economics.

5. Buzzacchi, L., Colombo, M.G. and Mariotti, S. (1995). Technological regimes and innovation in services: the case of the Italian banking industry, Research Policy, 24 (1), pp. 151-168.

6. Damanpour, F. and Gopalakrishnan, S. (2001). The dynamics of the adoption of product and process innovations in organisations, Journal of Management Studies, 38 (1), pp. 45-65.

7. Damanpour, F., Szabat, K.A. and Evan, W.M. (1989). The relationship between types of innovation and organizational performance, Journal of Management Studies, 26 (6), pp. 587-601.

8. Dan, A. (2013). Toward a Supply-Side Theory of Financial Innovation, Journal of Comparative Economics, 41 (2).

9. De Young, R., Lang, W.W. and Nolle, D.L. (2007). How the internet affects output and performance at community banks, Journal of Banking and Finance, 31 (4), pp. 1033-1060.

10. Dow, Jr. J.P. (2007). The adoption of web banking at credit unions, The Quarterly Review of Economics and Finance, 47 (3), pp. 435-448.

11. Ettlie, J.E. (1995). Product-process development integration in manufacturing, Management Science, 41 (7), pp. 1224-1237.

12. Fuentelsaz, L., Gomez, J. and Polo, Y. (2003). Intrafirm diffusion of new technologies: an emprirical application, Research Policy, 32 (4), pp. 533-551.

13. Furst, K., Lang, W.W. and Nolle, D.E. (2002). Internet banking, Journal of Financial Services Research, Août-Octobre, 23 (3), pp. 95-123.

14. Herrera, A.M. and Minetti, R. (2007). Informed finance and technological change: evidence from credit relationships. Journal of Financial Economics, 83 (1), pp. 223-269.

15. Iannotta, G., Nocera, G. and Sironi, A. (2007). Ownership structure, risk and performance in the European banking industry, Journal of Banking and Finance, 30 (7), pp. 2127-2149.

16. Jaccard, J. and Wan, C.K. (1996). LISRL Approaches to Interaction Effects in Multiple Regression, Series: Quantitative Applications in the Social Scies, 114, Sage University Paper.

17. Jaccard, J., Teitel, L. and Turrisi, R. (2003). Interaction effects in multiple regression, Series: Quantitative Applications in the Social Sciences, 72, Sage Publications.

18. Leaven, L. and Levine, R. (2007). Is there a diversification discount in financial conglomerates? Journal of Financial Economics, 85 (2), Août, pp. 331-337.

19. Mabrouk, A. and Mamoghli, C. (2010). Dynamic of Financial Innovation and Performance of Banking Firms: Context of an Emerging Banking Industry, International Research Journal of Finance and Economics, 51, pp. 17-37.

20. Mohieldin, M. and Nasr, S. (2007). On bank privatization: the case of Egypt, The Quarterly Review of Economics and Finance, 46 (5), février, pp. 707-725.

21. Porter, M.E. (2004). Competitive strategy. New York edition.

22. Roberts, P.W. and Amit, R. (2003). The dynamics of innovative activity and competitive advantage: the case of Australian retail banking, 1981 to 1995, Organization Science, Mars /Avril, 14 (2), pp. 107-122.

23. Stiroh, K.J. (2006). A portfolio view of banking with interest and non interest activities, Journal of Money, Credit and Banking, 38 (5), pp. 1351-1361.

24. Sullivan, R.J. (2000). How has the adoption of internet banking affected performance and risk in banks. Financial Industry Perspectives, Federal Reserve Bank of Kansas City, December, pp. 1-16.

25. Walker, R.M. (2004). Innovation and organizational performance: Evidence and a research agenda. Advanced Institute of Management Research Paper $\mathrm{N}^{\circ} 002$, June. 